\title{
DISIPLIN KERJA PEMANEN KELAPA SAWIT DI PT. HARAPAN SAWIT LESTARI CARGILL KETAPANG
}

\author{
Chaerul Aziz Fatoni, Dewi Kurniati', Anita Suharyani \\ Program Studi Agribisnis, Fakultas Pertanian, Universitas Tanjungpura \\ Jl. Prof. Dr. H. Hadari Nawawi, Pontianak 78124 \\ *Corresponding author: dewi.kurniati@faperta.untan.ac.id
}

\begin{abstract}
PT. Harapan Sawit Lestari Cargill still has undisciplined workers. The purpose of this study was to determine the level of work discipline and the factors that influence the Work Discipline of Oil Palm Harvesters at PT. Harapan Sawit Lestari Cargill Ketapang. The method used in this research is a descriptive quantitative method using 100 respondents taken by positive sampling and data analysis used is Structural Equation Modeling (SEM) Lisrell software 8.80. The results are the level of discipline of oil palm harvest workers at PT. Harapan Sawit Lestari Cargill Ketapang is categorized as good. Variables that influence discipline are the leader justice retribution and firmness. PT. Harapan Sawit Lestari Cargill Lestari must pay attention to the level of labor discipline by conducting direct supervision. The foreman must be more assertive and fair to undisciplined workers who are given punishment or sanctions to provide a deterrent effect. Workers who obey the rules are given rewards in bonuses to motivate other workers not to violate. Treatment of workers must provide health facilities in adequate health insurance.
\end{abstract}

Keywords: workers, work discipline, SEM

\begin{abstract}
Abstrak: PT. Harapan Sawit Lestari Cargill Ketapang mengembangkan sumber daya manusianya terutama pada tingkat kedisiplinan buruh bagian panen. PT. Harapan Sawit Lestari Cargill masih terdapat pekerja buruh panen yang tidak menggunakan safety pada saat melakukan panen yang dapat membahayakan dan merugikan perusahaan. Tujuan dari penelitian ini adalah mengetahui tingkat disiplin kerja dan faktor yang memengaruhi disiplin kerja pemanen kelapa sawit di PT. Harapan Sawit Lestari Cargill Ketapang. Penelitian ini menggunakan metode kuantitatif deskriptif dengan 100 responden yang diambil secara purposive sampling dan dianalisis dengan Structural Equation Modelling (SEM) software Lisrell 8.80. Hasil penelitian menunjukkan tingkat kedisiplinan buruh panen sawit di PT. Harapan Sawit Lestari Cargill Ketapang dikategorikan baik. Variabel yang berpengaruh terhadap kedisiplinan yaitu keadilan pemimpin, balas jasa dan ketegasan. PT. Harapan Sawit Lestari Cargill Lestari harus memperhatikan tingkat kedisiplinan buruh dengan melakukan pengawasan langsung. Mandor harus bersikap lebih tegas dan adil kepada buruh yang tidak disiplin diberikan hukuman atau sanksi untuk memberikan efek jera. Buruh yang menaati aturan diberikan penghargaan berupa bonus guna memotivasi buruh lain agar tidak melakukan pelanggaran. Perusahaan harus memberikan fasilitas kesehatan berupa jaminan kesehatan yang layak.
\end{abstract}

Kata kunci: buruh, disiplin kerja, SEM

\section{PENDAHULUAN}

Sumber daya manusia selalu berperan aktif dan dominan dalam setiap organisasi, baik organisasi swasta maupun pemerintah, karena manusia menjadi perencana, pelaku dan penentu terwujudnya tujuan organisasi. Selain itu, sumber daya manusia juga dianggap 
Fatoni, C. A., Kurniati, D., Suharyani, A. : Disiplin Kerja Pemanen Kelapa Sawit ...

penting karena perannya yang sangat dominan dalam merencanakan, mengorganisasikan, menggerakkan, maupun mengontrol segala hal yang berkaitan dengan masalah karyawan.

Disiplin adalah sikap kesediaan dan kerelaan seseorang untuk mematuhi dan menaati norma-norma peraturan yang berlaku disekitarnya (Sutrisno, 2011). Disiplin karyawan yang baik akan mempercepat tujuan perusahaan, sedangkan disiplin yang merosot akan menjadi penghalang dan memperlambat pencapaian tujuan perusahaan.

Berbicara tentang disiplin kerja karyawan demi meningkatkan prestasi kerjanya yang mampu mencapai suatu target perusahaan, Disiplin adalah suatu kondisi yang tercipta dan terbentuk melalui proses dari serangkaian perilaku yang menunjukkan nilai-nilai ketaatan, kepatuhan, keteraturan, dan ketertiban. Kedisiplinan adalah kunci keberhasilan suatu organisasi dalam mencapai tujuannya (Prijodarminto, 2004).

Kesadaran setiap individu untuk melaksanakan setiap peraturan dan normanorma yang berlaku dalam organisasi merupakan gambaran terhadap pelaksanaan disiplin, karena tanpa adanya kesadaran tersebut akan sulit untuk melaksanakan disiplin dalam bekerja. Peraturan dan norma-norma yang telah ditetapkan terhadap pegawai merupakan satu kesatuan yang tak terpisahkan. Demikian halnya jika peraturan tidak berjalan dengan baik akan mengakibatkan tindakan indisipliner yang merugikan organisasi dan karyawan itu sendiri.

PT. Harapan Sawit Lestari Cargill Ketapang merupakan satu di antara perusahaan besar yang mampu mempekerjakan banyak karyawan. Hal tersebut tidak berarti perusahan PT. Harapan Sawit Lestari Cargill Ketapang Estate Kebanteng Manis Mata tidak mengalami permasalahan. Satu diantara permasalahan yang dihadapi oleh PT. Harapan Sawit Lestari Cargill Ketapang Estate Kebanteng Manis Mata yakni permasalahan pada keselamatan dan kesehatan kerja pemanen kelapa sawit dimana pada tahun 2015-2019 tingkat kecelakaan kerja lebih tinggi dibandingkan dengan karyawan lain. Tabel 1 menyajikan data kecelakaan kerja karyawan.

Data kecelakaan kerja di PT. Harapan Sawit Lestari Estate Kebanteng menunjukkan bahwa dari 17 kecelakaan yang terjadi, 70,59\% kecelakaan terjadi kepada pemanen, $11,76 \%$ kecelakaan terjadi kepada penyemprot, dan $17,65 \%$ kecelakaan terjadi kepada penebas.

Tabel 1. Data kecelakaan kerja PT Harapan Sawit Lestari Cargill Ketapang

\begin{tabular}{|c|c|c|c|}
\hline No & Tanggal & Lokasi & Keterangan \\
\hline 1 & 15 Februari 2015 & Blok A 4 & Karyawan terluka tergigit ular saat menebas \\
\hline 2 & 27 oktober 2015 & Blok C23 & Pemanen terluka karena stik egrek patah \\
\hline 3 & 10 Desember 2015 & Blok D 25 & $\begin{array}{l}\text { Pemanen meninggal karena stik egrek yang terpental ketika } \\
\text { menurunkan pelepah }\end{array}$ \\
\hline 4 & 4 Januari 2016 & Blok E 30 & Pemanen terluka karena tergigit ular \\
\hline 5 & 27 Agustus 2016 & Blok D 25 & Pemanen meninggal karena tertimpa TBS \\
\hline 6 & 11 September 2016 & Blok F 2 & Penyemprot keracunan rondap \\
\hline 7 & 23 Desember 2016 & Blok E 23 & Pemanen meninggal karena tertimpa TBS \\
\hline 8 & 20 Mei 2017 & Blok E 33 & Karyawan terluka terkena parang saat menebas \\
\hline 9 & 5 Oktober 2017 & Blok F 42 & Mata pemanen terkena debu sawit \\
\hline 10 & 7 Desember 2017 & Blok A 25 & Pemanen terluka terkena ujung pelepah kelapa sawit \\
\hline 11 & 12 Maret 2018 & Blok C 12 & $\begin{array}{l}\text { Karyawan mengalami kebutaan karena terkena racun saat } \\
\text { menyemprot }\end{array}$ \\
\hline 12 & 1 April 2018 & Blok D 16 & Pemanen meninggal dikarenakan tertimpa egrek \\
\hline 13 & 6 Agustus 2018 & Blok A 33 & Betis pemanen terkena sabitan egrek \\
\hline 14 & 9 September 2018 & Blok G 44 & Pemanen mengalami kebutaan karena tertimpa brondolan \\
\hline 15 & 18 Januari 2019 & Blok C 29 & $\begin{array}{l}\text { Pemanen mengalami luka parah di bagian kepala karena } \\
\text { tertimpa TBS }\end{array}$ \\
\hline 16 & 12 April 2019 & Blok F 19 & $\begin{array}{l}\text { Pemanen meninggal karena terkena sabitan egrek ketika } \\
\text { istirahat }\end{array}$ \\
\hline 17 & 19 Juli 2019 & Blok D 13 & Pemanen meninggal karena tertimpa TBS \\
\hline
\end{tabular}

Sumber : Data Primer, 2019 
Fatoni, C. A., Kurniati, D., Suharyani, A. : Disiplin Kerja Pemanen Kelapa Sawit ...

Data kecelakaan kerja rata-rata tiap tahunnya hanya sedikit namun perlu diperhatikan. Kecelakaan kerja dapat mengakibatkan karyawan sakit, karyawan yang sakit akan menyebabkan karyawan tersebut tidak dapat bekerja dengan baik sehingga tingkat produktivitas kerjanya akan mengalami penurunan dibanding waktu karyawan tersebut sehat.

Buruh yang mengalami kecelakan kerja akan berdampak negatif bagi perusahaan, karena perusahaan menanggung biaya pengobatan buruh tersebut walaupun buruh tersebut sudah tercatat dalam BPJS ketenagakerjaan namun biaya tersebut ditanggung terlebih dahulu oleh perusahaan. Selain itu perusahaan juga harus membayar gaji bagi buruh yang mengalami kecelakaan dan tidak bisa melakukan pekerjaan sehingga dapat menghambat proses produksi.

Adapun penelitian terdahulu yang digunakan oleh penulis merupakan penelitian yang memiliki kesamaan variabel maupun teori (Sayudha, 2013; Kusuma, 2012; Elpitra, 2012; Sri, 2010). Penelitian Fransiska (2015) diambil sebagai referensi karena memiliki persamaan variabel, teori dan alat analisis yaitu SEM. Kesimpulan dari beberapa penelitian terdahulu diatas adalah bahwa untuk meningkatkan kedisiplinan pekerja dapat dilakukan dengan memperhatikan faktor-faktor yang memengaruhi disiplin kerja.

Disiplin kerja buruh sangat berperan penting dalam perusahaan, tindakan tidak disiplin kerja buruh akan menyebabkan kecelakaan kerja yang akan merugikan perusahaan, maka dari itu penelitian tentang kedisiplinan buruh penting untuk dilakukan guna mengurangi risiko kecelakaan kerja. Adapun tujuan yang ingin didapat dari penelitian ini adalah mengetahui tingkat Disiplin Kerja Pemanen Kelapa Sawit di PT Harapan Sawit Lestari Cargill Ketapang dan mengetahui faktor yang paling memengaruhi Disiplin Kerja Pemanen Kelapa Sawit di PT Harapan Sawit Lestari Cargill Ketapang.

\section{METODE PENELITIAN}

Penelitian ini dilakukan di Kabupaten Ketapang Kecamatan Manis Mata tepatnya di Kebun Kebanteng Estate PT. Harapan Sawit Lestari Cargill. Lokasi penelitian dipilih secara sengaja dengan pertimbangan bahwa perusahaan tersebut sudah ada sejak 1995. Metode yang digunakan dalam penelitian ini adalah metode deskriptif kuantitatif. Populasi dalam penelitian ini adalah seluruh pemanen kelapa sawit yang bekerja di PT Harapan Sawit Lestari, khususnya para pemanen yang bekerja di Kebun Kebanteng Estate yaitu sebanyak 397 pemanen. Sampel dalam penelitian ini sebanyak 100 responden yang dipilih secara sengaja. Tahap pertama yang dilakukan dalam menganalisis penelitian ini adalah menguji validitas dan reliabilitas. Uji validitas diperlukan saat mengukur validitas pertanyaan pada kuesioner. Pertanyaan dikatakan valid apabila mampu menjelaskan dan mengungkapkan sesuatu yang akan diukur oleh kuesioner yang digunakan. Setelah lolos uji validitas dan reliabilitas, langkah selanjutnya adalah menggunakan keseluruhan model atau menganalisis keterterapan data di Lisrel, yang disebut dengan Goodness of Fit (GOF). Tahapan Uji kesesuaian model terkait dengan analisis terhadap ukuran Goodness of Fit (GOF). Setelah model awal dilakukan modifikasi indeks atau respesifikasi, selanjutnya model tersebut diuji kembali menggunakan acuan kriteria GOF dengan mencocokkan nilai standar atau target kecocokan terhadap nilai GOF statistik hasil estimasi model akhir. Pada tahap ini diperiksa tingkat kecocokan antara data dan model. Teknik pengumpulan data dilakukan melalui wawancara, penyebaran kuesioner dan variabel yang meliputi disiplin kerja, keadilan, balas jasa, waskat dan ketegasan.

\section{HASIL DAN PEMBAHASAN}

\section{Karakteristik Responden}

Karakteristik Responden dapat diklasifikasikan menurut jenis kelamin, usia, pengalaman kerja, tingkat pendidikan dan pendapatan. Terdapat 100 responden yang dijadikan sampel dalam penelitian ini, yaitu pemanen kelapa sawit PT Harapan Sawit Lestari, khususnya yang bekerja di Kebun Kebanteng. Tabel 2 menjelaskan bahwa jenis kelamin responden pada penelitian ini keseluruhan laki-laki. Hal ini dikarenakan kegiatan panen buah kelapa sawit merupakan kegiatan yang mengharuskan seseorang terjun langsung kelapangan atau lahan sawit. 
Fatoni, C. A., Kurniati, D., Suharyani, A. : Disiplin Kerja Pemanen Kelapa Sawit ...

Tabel 2. Karakteristik responden

\begin{tabular}{lccc}
\hline $\begin{array}{l}\text { Karakteristik } \\
\text { Responden }\end{array}$ & Keterangan & Jumlah & $\begin{array}{c}\text { Persentase } \\
(\%)\end{array}$ \\
\hline Jenis Kelamin & Laki-laki & 100 & 100 \\
& Perempuan & 0 & 0 \\
\hline Umur & $22-27$ & 20 & 20 \\
& $28-33$ & 43 & 43 \\
& $34-39$ & 16 & 16 \\
& $40-45$ & 9 & 9 \\
& $46-40$ & 12 & 12 \\
\hline Lama & $2-5$ & 37 & 37 \\
Bekerja & & & \\
& $6-9$ & 26 & 26 \\
& $10-13$ & 22 & 22 \\
& $14-17$ & 10 & 10 \\
\hline Pendidikan & $18-21$ & 5 & 5 \\
\hline & SD & 84 & 84 \\
\hline
\end{tabular}

Sumber : Data Primer Diolah, 2020

Pekerjaan ini merupakan pekerjaan berat yang tidak seharusnya dilakukan oleh perempuan. Perempuan pada umumnya bekerja pada perusahaan sawit sebagai buruh penyemprotan, buruh kutip biji sawit dan lain sebagainya yang dalam bekerjanya tidak melakukan pekerjaan yang berat (Samosir dan Bahri, 2017).

Tabel 2 menjelaskan bahwa umur didominasi oleh responden berumur 28-33 tahun, umur tersebut masih tergolong muda dan produktif sehingga ketika melakukan kegiatan panen akan lebih optimal. Umur sangat memengaruhi kuantitas serta kualitas kerja karyawan, jika perusahaan mempekerjakan karyawan yang sudah berusia lanjut maka sangat besar kemungkinan kualitas kerja akan menurun dan timbulnya kecelakaan kerja yang dialami oleh karyawan panen sangat rentan karena semakin tua usia kemampuan fisik untuk bekerja sudah berkurang dan mudah cepat lelah dalam melakukan pekerjaan panen (Silaban et al., 2016). Berdasarkan Tabel 2 menjelaskan bahwa pemanen kelapa sawit di PT. Harapan Sawit Lestari Cargill Ketapang didominasi oleh responden dengan rata-rata lama bekerja selama 2-5 tahun. Hal ini terjadi karena sering adanya pergantian tenaga kerja yang lama dengan tenaga kerja baru. Hal tersebut termasuk dalam kategori lama bekerja karena rata-rata di atas 3 tahun (Handoko, 2003). Pemanen dengan pengalaman kerja yang cukup, sehingga dapat bekerja dengan baik dan menguasai teknik memanen atau mendodos buah kelapa sawit, sehingga tidak membutuhkan waktu lama untuk menebang tandan kelapa sawit dengan kata lain lebih berpengalaman dibandingkan dengan pemanen lainnya, lebih mahir memanen buah sawit, sehingga hasil panen yang dihasilkan lebih banyak (Sipriani et al., 2017). Berdasarkan Tabel 2 menjelaskan bahwa pemanen kelapa sawit di PT. Harapan Sawit Lestari Cargill Ketapang didominasi oleh responden dengan pendidikan SD. Hal tersebut dapat diketahui bahwa tingkat pendidikan untuk tenaga kerja panen tidak berpengaruh pada produktivitas tenaga kerja panen yang dapat dipahami karena kondisi lingkungan tempat bekerja tidak memerlukan tingkat pendidikan yang tinggi dan hanya membutuhkan kekuatan fisik dan keterampilan tenaga kerja juga (Sutrisno, 2011; Suma'mur, 2009; Notoatmodjo, 2009).

\section{Uji Validitas dan Reliabilitas}

Uji validitas diperlukan saat mengukur validitas pertanyaan pada kuesioner. Pertanyaan dikatakan valid apabila mampu menjelaskan dan mengungkapkan sesuatu yang akan diukur oleh kuesioner yang digunakan. Penelitian ini mempunyai 29 pengukuran yang menjadi dasar pertanyaan yang diajukan kepada 100 responden. Hasil perhitungan menunjukkan bahwa semua indikator dapat dikatakan baik, dan jawaban responden atas pertanyaan yang digunakan untuk mengukur masing-masing indikator konsisten dan memiliki nilai $\mathrm{SLF} \geq 0,50$ Menunjukkan valid atau tidak ada offending estimate, Nilai $\mathrm{CR} \geq 0,60$ dan $\mathrm{VE} \geq$ 0,50 menunjukkan reliabilitas yang baik.

\section{Deskriptif Jawaban Responden terhadap Indikator Disiplin Kerja Pemanen Sawit}

Analisis hasil jawaban kuesioner responden variabel kedisiplinan diukur melalui indikator ketepatan waktu, penggunaan peralatan dengan baik, tanggung jawab dan taat aturan (Hasibuan 2009). Indikator ketepatan waktu responden dominan menjawab selalu hadir tepat waktu, dengan tingkat kehadiran kurang dari 5\%. Hal ini dikarenakan buruh setiap ada perayaan hari besar buruh sering meminta tambah cuti libur karena hari libur yang diberikan oleh perusahaan dianggap terlalu singkat oleh buruh. Responden pada saat apel pagi selalu hadir tepat waktu pukul 05.00 karena ada absensi kehadiran karyawan yang dilakukan oleh mandor panen. Indikator penggunaan peralatan 
Fatoni, C. A., Kurniati, D., Suharyani, A. : Disiplin Kerja Pemanen Kelapa Sawit ...

dengan baik responden dominan menjawab sesekali melepas perlengkapan kerja di kondisi tertentu, hal ini dikarenakan pada pada saat memakai perlengkapan kerja buruh merasa panas dan gerah selain itu buruh juga kurang terbiasa melakukan kegiatan panen memakai perlengkapan tersebut dan merasa tidak leluasa dalam bekerja. Indikator tanggung jawab responden dominan menjawab selalu menyelesaikan tugas yang diberikan tepat waktu meskipun sesekali melakukan kesalahan hal ini dikarenakan buruh kadang lalai terhadap aturan misalnya buruh kadang memanen buah yang masih mentah. Indikator taat aturan responden dominan menjawab sesekali tidak menaati aturan-aturan prosedur kerja dan ikuti instruksi yang diberikan atasan hal ini terjadi karena kelalaian buruh sendiri dan tidak adanya ketegasan oleh mandor panen.

Variabel keadilan diukur melalui indikator sumber daya dan fasilitas serta keikutsertaan dalam pengambilan keputusan responden menginginkan bahwa ketika ada keputusan mengenai SOP buruh semua buruh ikut terlibat dalam mengemukakan pendapat dalam pengambilan keputusan, hal ini agar tidak ada pihak yang saling dirugikan atas peraturan tersebut. Indikator sumberdaya dan fasilitas responden dominan menjawab kesempatan berprestasi dalam bekerja terbuka bagi seluruh rekan kerja buruh panen tidak ingin menjadi buruh panen selamanya melainkan menginginkan kenaikan pangkat seperti menjadi mandor dan sebagainya. Indikator pengambilan keputusan responden dominan menjawab memahami tanggung jawab orang lain terkait dengan tugas mereka, dan bersedia mempertimbangkan saran orang lain.

Variabel balas jasa diukur melalui indikator gaji, bonus dan pengobatan. Indikator gaji responden dominan menjawab gaji yang diberikan sesuai UMR yang berlaku karena jika gaji yang diberikan hanya sebatas jumlah buah sawit yang dipanen terkadang hasilnya bisa dibawah gaji UMR disebabkan oleh jumlah buah sawit yang mengalami penurunan. Indikator bonus responden dominan menjawab bonus yang diberikan sesuai dengan premi panen responden menginginkan apabila pekerjaannya melebihi target yang telah ditentukan maka kelebihan buah sawit yang dipanen tersebut dijadikan premi agar menambah penghasilan, indikator pengobatan responden dominan menjawab pendaftaran asuransi kesehatan bagi seluruh karyawan perusahaan dan biaya dipotong dari gaji karyawan hal ini diperlukan bagi buruh terutama pada buruh panen karena memiliki resiko tingi dalam melakukan pekerjaan memanen buah sawit.

Variabel waskat (pengawasan ketat) diukur melalui indikator pemantauan, pemeriksaan, dan evaluasi. Indikator pemantauan responden dominan menjawab mandor panen selalu memberikan arahan terkait tata cara pemanen tandan buah segar, bagaimana cara memanen TBS dengan baik dan benar agar tidak mendapatkan sangsi. Indikator pemeriksaan responden dominan menjawab mandor panen turun ke lapangan untuk memastikan pemanen menggunakan alat perlengkapan panen demi keselamatan kerja mandor panen selalu melakukan pengamatan atau pengawasan secara langsung di lapangan mengenai alat perlengkapan panen agar buruh selalu taat terhadap aturan yang berlaku, indikator evaluasi responden dominan menjawab melakukan penilaian kerja berdasarkan pendapat rekan kerja dan tidak mengawasi secara langsung ketika buruh selesai melakukan pekerjaan dalam memanen sawit maka diperlukan evaluasi baik cara bekerja maupun hal lain, untuk menilai hal ini maka rekan kerja merupakan seseorang yang cocok dalam melakukan penilaian.

Variabel ketegasan diukur melalui indikator menegur dan bijak mengambil keputusan. Indikator menegur responden dominan menjawab bertindak tegas dan tidak memihak, serta ungkapkan pendapat dengan jelas ketika dalam ketegasan tidak pandang bulu serta tidak memihak kepada siapapun.

\section{Analisis Bagian Indikator Disiplin Kerja Pemanen Sawit}

Kedisiplinan kerja pemanen di PT. Harapan Sawit Lestari Cargill Ketapang dapat dikategorikan cukup baik dilihat dari Tabel 3. Hal ini terlihat hasil perhitungan dari jawaban kuesinoner responden yang menunjukkan angka 361.75 yang dikategorikan baik. Disiplin yang baik adalah terdiri dari disiplin waktu, tugas, serta disiplin tingkah laku (Sutrisna dan Ulina, 2015). 
Fatoni, C. A., Kurniati, D., Suharyani, A. : Disiplin Kerja Pemanen Kelapa Sawit ...

Tabel 3. Skor ideal kedisiplinan

\begin{tabular}{lcc}
\hline \multicolumn{1}{c}{ Indikator } & $\begin{array}{c}\text { Skor } \times \\
\text { Persentase } \\
\text { Jawaban }\end{array}$ & Total \\
\hline 1. Ketepatan Waktu & $6 \times 5$ & 30 \\
& $55 \times 4$ & 220 \\
& $38 \times 3$ & 114 \\
& $1 \times 2$ & 2 \\
\hline 2. Penggunaan & $18 \times 5$ & 75 \\
Peralatan Dengan & $43 \times 4$ & 172 \\
Baik & $36 \times 3$ & 108 \\
& $3 \times 2$ & 6 \\
\hline 3. Tanggung Jawab & $8 \times 5$ & 40 \\
& $48 \times 4$ & 192 \\
& $41 \times 3$ & 123 \\
& $3 \times 2$ & 6 \\
\hline 4. Taat Aturan & $12 \times 5$ & 60 \\
& $39 \times 4$ & 156 \\
& $45 \times 3$ & 135 \\
& $4 \times 2$ & 8 \\
\hline Total & & 1447 \\
\hline Rata-Rata & & 361.75
\end{tabular}

Sumber: Data Primer Diolah, 2020

Namun terdapat beberapa situasi buruh yang tidak sesuai fakta di lapangan. Misalkan pada saat apel pagi buruh memakai perlengkapan memanen, namun saat di lapangan buruh melepas perlengkapan panen seperti helm, sepatu dan lain sebagainya. Selain itu ada pula buruh yang tidak mematuhi peraturan panen dengan memanen buah yang kurang matang dan meninggalkan buah yang masih di pohon. Kedisiplinan yang dikategorikan cukup baik harus lebih ditingkatkan supaya perusahaan tidak banyak mengalami kerugian dengan banyaknya buruh yang melanggar aturan.

\section{Analisis Estimasi Disiplin Kerja Pemanen Sawit}

Uji validitas variabel indikator dilakukan dengan melihat nilai standard loading factor (SLF) pada setiap variabel laten dengan indikatornya. Berdasarkan nilai SLF semua indikator sudah memenuhi standar nilai SLF > 0,50 sehingga tidak ada indikator yang dikeluarkan dari model. Setelah uji validitas model, dilakukan reliabilitas pada model menggunakan construct reliability (CR). Reliabilitas model dalam penelitian ini dapat dikatakan baik dan nilai $\mathrm{CR}>0,60$ dan VE> 0,5. Hasil estimasi SLF akhir ditunjukkan pada Gambar 1.

\section{Uji kesesuaian model (Goodness of Fit) Sebelum Respisifikasi}

Setelah lolos uji validitas dan reliabilitas, langkah selanjutnya adalah menggunakan keseluruhan model atau menganalisis keterterapan data di Lisrel, yang disebut dengan Goodness of Fit (GOF). Tahapan Uji kesesuaian model terkait dengan analisis terhadap ukuran Goodness of Fit (GOF). Pada tahap ini diperiksa tingkat kecocokan antara data dan model. Ada beberapa ukuran kecocokan yang dapat digunakan secara bersama-sama atau kombinasi membuktikan bahwa model keseluruhan bagus. Pengujian

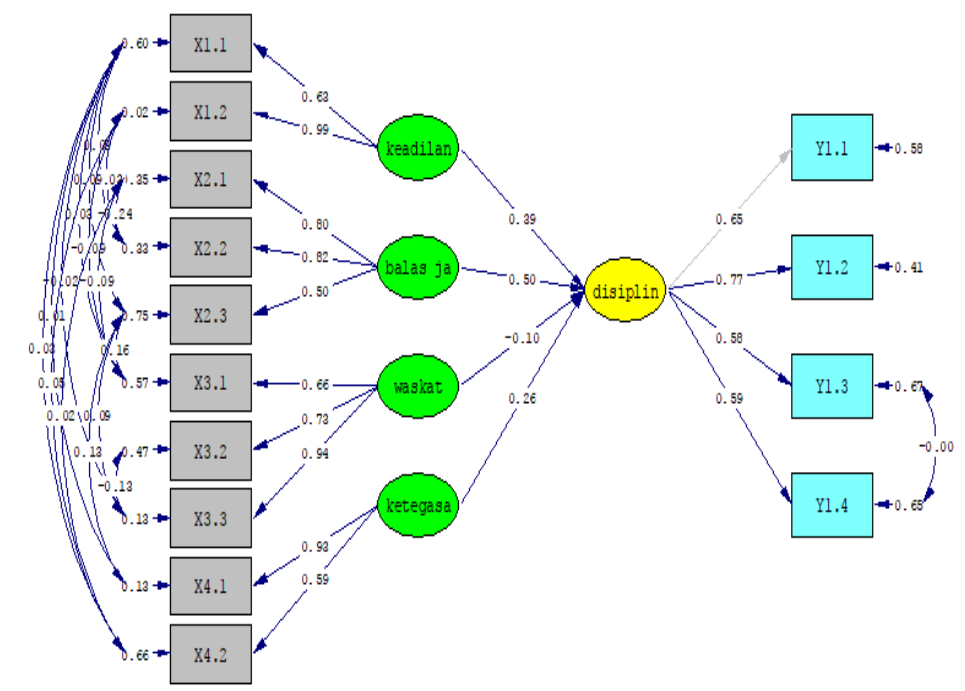

Gambar 1. Path diagram Standarized Loading Factor model struktural Sumber: Data Primer Diolah, 2020 
Fatoni, C. A., Kurniati, D., Suharyani, A. : Disiplin Kerja Pemanen Kelapa Sawit ...

dilakukan dengan cara mencocokkan kriteria ukuran yang sudah ditetapkan terhadap nilai GOF statistik hasil estimasi model awal sebelum terdapat 14 ukuran yaitu chi-square, X2, NCP, SNCP, RMSEA, ECVI, AIC, CAIC, NFI, NNFI, CFI, IFI, PGFI, RMR yang masuk kriteria baik dan selebihnya 5 ukuran yaitu PNFI, RFI, GFI, AGFI, CN yang masih kurang baik sehingga perlu dilakukan respisifikasi untuk mendapatkan nilai yang lebih baik.

Uji kesesuaian model (Goodness of Fit) Setelah Respisifikasi

Setelah model awal dilakukan modifikasi indeks atau respesifikasi, selanjutnya model tersebut diuji kembali menggunakan acuan kriteria GOF dengan mencocokan nilai standar atau target kecocokan terhadap nilai GOF statistik hasil estimasi model akhir. Ukuran GOF dan measurement error untuk setiap model pengukuran instrument pada model akhir dapat diketahui dari 19 ukuran GOF, 15 memenuhi standar yang baik dan 4 ukuran GOF kurang baik setelah dilakukan modifikasi indeks atau respesifikasi. Ukuran tersebut diantaranya yaitu X2/DF, NCP, SNCP, RMSEA, ECVI, AIC, CAIC, NFI, NNFI, CFI, IFI, GFI, PGFI dan RMR, dan 4 kriteria lainnya masih kurang baik yaitu PNFI, RFI, AGFI, CN.

\section{Analisis Hubungan Antar Variabel Structural Equation Modelling (SEM)}

Berdasarkan hasil estimasi dari model yang ditingkatkan, kuantitas atau koefisien yang diperoleh dapat menunjukkan hubungan antar variabel (Gambar 2 dan 3).

Model struktural menjelaskan bahwa variabel keadilan, balas jasa, ketegasan berpengaruh terhadap disiplin kerja pemanen kelapa sawit di PT. Harapan Sawit Lestari Cargill Ketapang. Variabel keadilan berpengaruh terhadap disiplin kerja pemanen kelapa sawit di PT. Harapan Sawit Lestari Cargill Ketapang. Keadilan juga mendorong terwujudnya disiplin pegawai, karena kodrat manusia selalu membuat orang merasa penting dan ingin diperlakukan sama. Keadilan dijadikan dasar kebijakan yang memberikan kompensasi atau hukuman, yang akan berdampak pada disiplin kerja yang baik. Manajer yang mahir dalam kepemimpinan dan selalu adil kepada semua bawahan. Keadilan yang baik dalam perusahaan akan menciptakan disiplin yang baik. Keadilan harus diterapkan dengan benar pada setiap perusahaan agar disiplin pegawai perusahaan juga baik. Hasil penelitian tersebut sejalan dengan penelitian lain yang mengemukakan sikap adil manager terhadap bawahannya akan memengaruhi

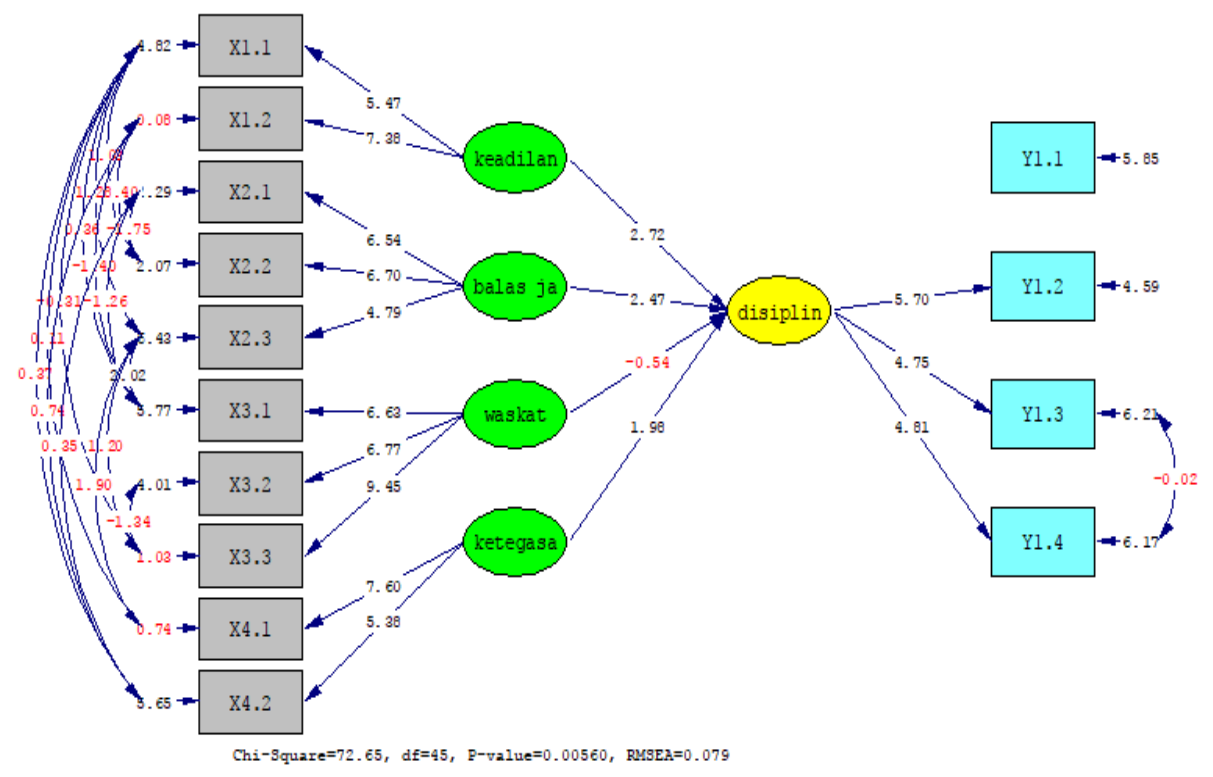

Gambar 2. t-value

Sumber: Data Primer Diolah, 2020 


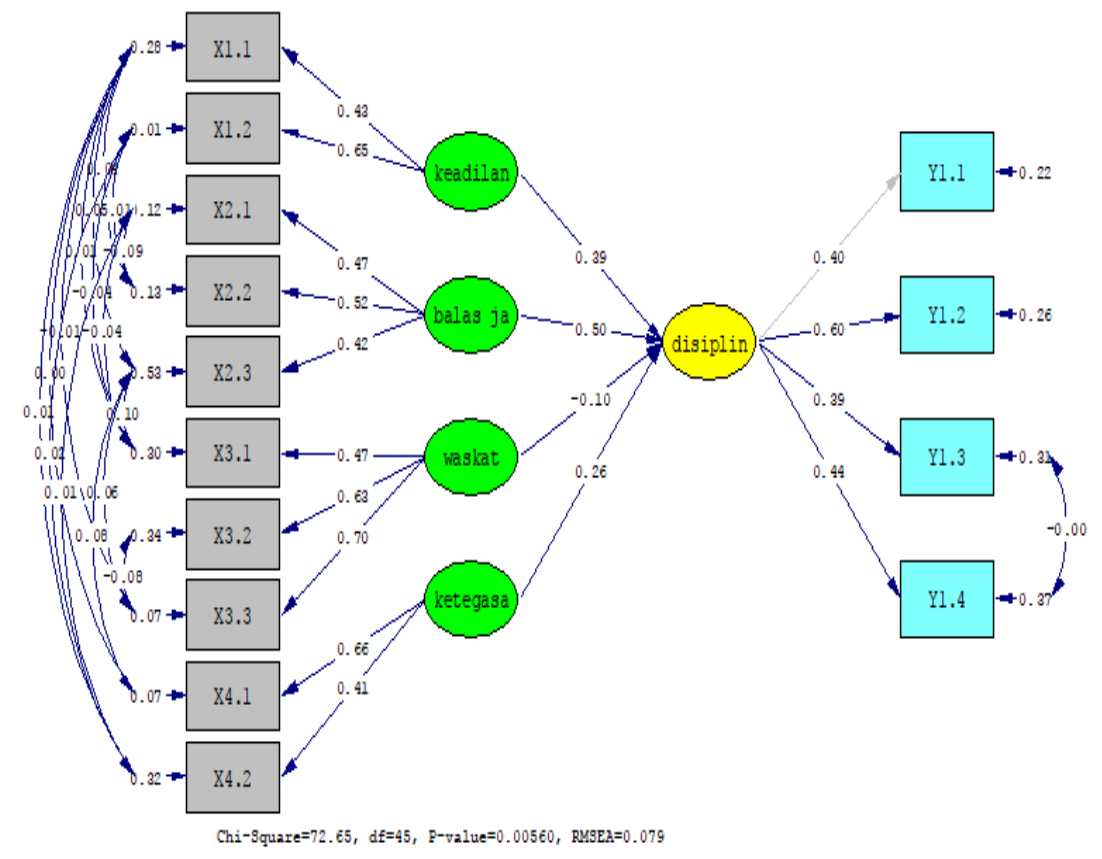

Gambar 3. Koefisien estimasi

Sumber: Data Primer Diolah, 2020

kedisiplinan karyawan (Syatiawan et al., 2016). Keadilan yang diberikan perusahaan terhadap pemanen dalam memberikan sumber daya dirasa cukup merata di perusahaan sehingga memberikan dampak positif terhadap terbanguhnya kedisiplinan pemanen, keadilan perusahaan dirasa masih cukup kurang baik dalam pengambilan keputusan karena beberapa pemanen merasa tidak pernah diberikan kesempatan untuk memberikan pendapat bahkan mereka harus terima begitu saja ketika adanya peraturan baru.

Variabel balas jasa berpengaruh terhadap disiplin kerja pemanen kelapa sawit di PT. Harapan Sawit Lestari Cargill Ketapang. Hal ini dikarenakan balas jasa adalah hal yang paling diutamakan dalam suatu perusahaan yaitu berkaitan dengan gaji, bonus, dan pengobatan. Gaji di perusahaan memang sudah diatur sesuai dengan premi yang dilakukan para pemanen akan tetapi para pemanen masih banyak yang mengeluh berkaitan dengan kenaikan gaji karena kebutuhan hidupnya selalu bertambah setiap harinya sehingga mereka harus berhutang terlebih dahulu di warung-warung. Bonus yang ada di perusahaan juga sangat memengaruhi kedisiplinan pemanen mereka lebih semangat melakukan pekerjaan ketika perusahaan memberikan bonus, tetapi bonus yang diberikan perusahaan juga mereka rasa kurang besar dan kurang merata. Pengobatan yang ada pada perusahaan juga memberikan pengaruh contohnya saja ketika mereka sakit maka mereka bisa berobat di klinik yang sudah disediakan oleh perusahaan sehingga tidak perlu mengeluarkan banyak biaya untuk pergi, tetapi banyak yang lebih memilih berobat di PUSKESMAS lain karena mereka merasa kurang cocok atau kurang bagusnya tenaga kesehatan yang bekerja. Pemberian gaji yang lebih baik bagi perusahaan akan membuat para pekerja merasa puas dan bersemangat dalam pekerjaannya. Hal ini penting karena gaji yang diberikan merupakan cerminan dari penilaian pekerjaan pekerja itu sendiri. Balas jasa penting untuk menciptakan kedisiplinan buruh, Intinya semakin banyak balas jasa yang diberikan kepada pekerja, semakin baik disiplin pekerja dan sebaliknya. Buruh akan semakin giat bekerja dan termotivasi untuk disiplin dengan adanya pemberian balas jasa (Suryani, 2013).

Variabel waskat (pengawasan melekat) tidak berpengaruh terhadap disiplin kerja kelapa sawit di PT. Harapan Sawit Lestari Cargill Ketapang. Hal ini karena berdasarkan observasi terlihat bahwa mandor panen tidak 
Fatoni, C. A., Kurniati, D., Suharyani, A. : Disiplin Kerja Pemanen Kelapa Sawit ...

benar-benar mengawasi buruh dalam melakukan panen buah kelapa sawit, ini dibuktikan dengan adanya buruh panen kelapa sawit yang masih melanggar aturan panen yang telah ditetapkan perusahaan seperti tidak menggunakan alat safety ketika melakukan panen dan pemanen memanen buah kelapa sawit yang masih mentah, meninggalkan buah yang telah, masak dipohon karena pemanen kurang teliti sehingga tidak melihat buah yang telah masak tertutupi oleh pelepah kelapa sawit. Hasil penelitian ini tidak sejalan dengan penelitian yang menyatakan waskat berpengaruh terhadap kedisiplinan buruh pada perusahaan (Putra et al., 2016). Pengawasan melekat (waskat) yang efektif memengaruhi kedisiplinan dan moral kerja buruh panen, dengan adanya pengawasan melekat (waskat) seorang mandor panen bisa langsung mengetahui kemampuan dan disiplin pada buruh panen. Waskat membutuhkan kesatuan aktif antara bawahan dan atasan untuk mencapai tujuan perusahaan demi mewujudkan kerjasama yang baik dan harmonis dalam perusahaan untuk mendukung pengembangan disiplin karyawan.

Variabel ketegasan berpengaruh terhadap disiplin kerja pemanen kelapa sawit di PT. Harapan Sawit Lestari Cargill Ketapang. Ketegasan merupakan suatu karakter pemimpin yang diperlukan oleh karyawan. Pemimpin yang berani tegas dalam bertindak, konsisten dalam mengambil tindakan serta adil dalam menjatuhkan hukuman adalah kunci keberhasilan pemimpin. Berdasarkan hasil observasi dilapangan mandor panen masih dianggap kurang tegas, dalam hal ini mandor panen dituntut harus tegas terhadap buruh terutama buruh yang tidak disiplin. Buruh panen yang masih sering melanggar aturan panen seperti tidak memakai peralatan panen, dalam hal ini mandor panen memberikan toleransi dalam menaati peraturan panen yang ditetapkan sehingga peningkatan disiplin yang diharapkan tidak terjadi. Seharusnya sikap mandor panen seperti ini tidak perlu dilakukan karena akan memengaruhi buruh panen yang tingkat disiplinnya baik artinya jika mandor panen tidak mengambil tindakan tegas kepada buruh yang tidak disiplin maka akan memengaruhi buruh yang kedisiplinannya baik. Hasil penelitian ini sejalan dengan penelitian yang menyatakan bahwa ketegasan seorang pemimpin akan memengaruhi tingkat kedisiplinan karyawan di suatu perusahaan (Putra et al., 2016).

Model pengukuran menjelaskan hubungan antar variabel laten dengan pengukurannya. Variabel keadilan diukur melalui indikator sumberdaya dan fasilitas. Indikator sumber daya dan fasilitas berkontribusi terhadap variabel keadilan dalam memengaruhi kedisiplinan pemanen kelapa sawit di PT. Harapan Sawit Lestari Cargill Ketapang. Sumber daya dan fasilitas Perusahaan kelapa sawit di PT. Harapan Sawit Lestari Cargill Ketapang telah berusaha menjalin hubungan yang baik dengan para buruh panen tersebut. Perusahaan telah membangun fasilitas tempat tinggal untuk para pekerja, tetapi perusahaan tidak memaksakan para pekerja untuk tinggal di fasilitas tersebut dikarenakan beberapa pekerja memilih tinggal di rumah sendiri karena tidak jauh dari perusahaan. Selain fasilitas rumah, perusahaan juga memberikan fasilitas tempat ibadah, peralatan kerja, beras dan lain sebagainya. Berdasarkan hasil kuesioner variabel sumber daya dan fasilitas, responden dominan memilih kesempatan berprestasi dalam bekerja terbuka bagi seluruh karyawan. Perusahaan memberikan kesempatan kepada seluruh karyawan untuk berprestasi tetapi ketika proses kenaikan jabatan tidak semua karyawan (pemanen) mendapatkan kesempatan tersebut, beberapa pemanen merasa bahwa pemilihan karyawan yang naik jabatan hanya secara sepihak sehingga tingkat kedisiplinan para pemanen kurang baik mereka merasa prestasi yang mereka lakukan tidak dilihat perusahaan. Hal ini menunjukkan bahwa dengan adanya pemberian kesempatan prestasi kepada buruh akan dapat meningkatkan kedisiplinan buruh, bekerja lebih giat lagi dan menaati peraturan perusahaan. Prestasi kerja dinilai PT. Harapan Sawit Lestari Cargill Ketapang meliputi kedisplinan buruh dengan datang dan berangkat tepat waktu, tidak pernah absen karena alasan yang tidak jelas, berkepribadian sopan dan santun, menjaga hubungan baik dengan atasan maupun sesama rekan kerja serta bertanggung jawab terhadap hasil kerjanya dan bertanggungjawab menjaga sarana dan prasarana yang digunakan. Hal ini sejalan dengan penelitian yang menyatakan bahwa dengan adanya pemberian prestasi kepada 
Fatoni, C. A., Kurniati, D., Suharyani, A. : Disiplin Kerja Pemanen Kelapa Sawit ...

karyawan maka karyawan akan meningkatkan kedisiplinannya (Meilani, 2020).

Indikator keikutsertaan dalam pengambilan keputusan berkontribusi pada variabel keadilan dalam memengaruhi kedisiplinan buruh panen pada PT. Harapan Sawit Lestari Cargill Ketapang. Berdasarkan hasil kuesioner pada indikator tersebut, responden dominan menjawab mampu berkoordinasi dan berkomunikasi dengan semua pihak serta menghargai pendapat dan pendapat orang lain secara konsisten. Buruh yang mampu berkoordinasi dan menghargai pendapat dan masukan orang lain akan memiliki kemampuan kerja sama yang baik antar tim. Pentingnya memiliki kerja sama yang baik agar buruh dapat berinteraksi dan saling tukar pendapat untuk membantu mencapai tujuan perusahaan. Hal ini didukung dengan partisipasi buruh didalam serikat pekerja dimana hubungan perburuhan merupakan hubungan berkesinambungan diantara sekelompok karyawan dengan manajemen perusahaan. Hal ini sejalan dengan Sipriani et al. (2017), yang menyatakan bahwa keterlibatan karyawan dalam pengambilan keputusan perusahaan sangat penting sehingga akan lebih memotivasi karyawan untuk melakukan pekerjaan dengan baik.

Variabel balas jasa diukur melalui indikator gaji, bonus dan pengobatan. Indikator gaji berkontribusi terhadap variabel balas jasa dalam memengaruhi kedisiplinan pemanen kelapa sawit di PT. Harapan Sawit Lestari Cargill Ketapang, sedangkan pengobatan tidak berkontribusi terhadap variabel balas jasa dalam memengaruhi kedisiplinan pemanen kelapa sawit di PT. Harapan Sawit Lestari Cargill Ketapang. Berdasarkan jawaban responden terkait gaji, responden dominan menjawab gaji yang diberikan sesuai dengan UMR yang berlaku. Sistem gaji pada perusahaan biasanya dihitung berdasarkan kehadiran atau hari kerja (HK). Upah yang diberikan perusahaan pada buruh sebesar Rp114.000 per hari, dikalikan dengan jumlah kehadiran buruh dalam 1 bulan. UMR Kabupaten Ketapang sebesar Rp2.860.322, berarti upah perusahaan kepada pekerja sesuai UMR yang berlaku pada kabupaten tersebut. Hal ini sejalan dengan penelitian yang menyatakan kecocokan yang benar antara keadilan sosial dan kesenjangan gaji akan mendorong pengembangan perusahaan (Guo, 2019).

Berdasarkan jawaban responden terkait bonus, responden dominan menjawab bonus yang diberikan sesuai dengan premi panen. Jika hasil panen melebihi patokan panen yang ditentukan oleh perusahaan, maka pemanen akan diberikan premi hasil panen. Selain itu untuk mendapatkan premi buruh panen juga dapat melibatkan anak dan istri untuk membantu mengutip buah kelapa sawit yang lepas dari tandan buah segar kelapa sawit yaitu brondolan dan membawanya ke tempat penimbangan hasil (TPH). Selain mendapatkan premi panen buruh juga mendapatkan premi basis yang diberikan ketika basis panen mencapai target volume panen dasar. Hasil ini sesuai dengan penelitian Munajat (2013) yang menyatakan bahwa premi panen berpengaruh terhadap kinerja karyawan dan dapat menimbulkan sikap disiplin karyawan. Berdasarkan jawaban responden terkait pengobatan, responden dominan menjawab bahwa pendaftaran asuransi kesehatan bagi seluruh karyawan perusahaan dan biaya dipotong dari gaji karyawan. Buruh PT. Harapan Sawit Lestari Cargill Ketapang sudah memiliki asuransi kesehatan melalui BPJS ketenagakerjaan. Sistem pembayaran asuransi ini dengan dipotong dari gaji buruh tersebut. Apabila buruh tersebut ingin memutuskan keluar dari perusahaan dan tidak mengalami sakit maka biaya yang dibayarkan tersebut dapat ditarik kembali dengan prosedur yang telah ditentukan.

Variabel pengawasan melekat (waskat) diukur melalui indikator pemantauan, pemeriksaan dan evaluasi. Indikator pemantauan dan pemeriksaan berkontribusi terhadap variabel waskat (pengawasan ketat) dalam memengaruhi kedisiplinan pemanen kelapa sawit di PT. Harapan Sawit Lestari Cargill Ketapang. Evaluasi tidak berkontribusi terhadap variabel waskat (pengawasan ketat) dalam memengaruhi kedisiplinan pemanen kelapa sawit di PT. Harapan Sawit Lestari Cargill Ketapang. Pengawasan melekat (waskat) dilakukan oleh atasan untuk mengetahui tingkat kedisiplinan dari buruh tersebut demi menjadikan buruh yang taat aturan. Pengawasan melekat yang dilakukan oleh PT. Harapan Sawit Lestari kurang baik dikarenakan mandor panen mengawasi buruh 
Fatoni, C. A., Kurniati, D., Suharyani, A. : Disiplin Kerja Pemanen Kelapa Sawit ...

seadanya saja ketika melakukan kegiatan panen. Sehingga ketika mandor panen tidak mengawasi, pemanen banyak yang melanggar peraturan yang ditetapkan perusahaan seperti melepaskan helm dan menyimpan alat panen secara sembarangan ketika beristirahat. Hal ini tidak sejalan dengan Utari (2015) yang menyatakan bahwa variabel pengawasan melekat memberi pengaruh positif terhadap kedisiplinan kerja karyawan.

Variabel ketegasan diukur melalui indikator menegur dan bijak mengambil keputusan. Indikator menegur dan bijak mengambil keputusan berkontribusi terhadap variabel ketegasan dalam memengaruhi kedisiplinan pemanen kelapa sawit di PT. Harapan Sawit Lestari Cargill Ketapang. Ketegasan pemimpin yang berani menindak tegas terhadap bawahannya maka akan menciptakan kedisiplinan bawahannya tersebut karena tindakan tegas dapat membentuk kebiasan buruh sehingga dapat mencapai tingkat kedisiplinan yang lebih baik. Hal ini sejalan dengan penelitian yang menyatakan ketegasan pemimpin berpengaruh positif terhadap disiplin kerja karyawan (Setiawan, 2011). Ketegasan mandor panen yang ada di PT. Harapan Sawit Lestari masih kurang baik, dimana apabila terdapat buruh yang melanggar aturan perusahaan dan buruh tersebut kenal baik atau merupakan kerabat mandor, maka buruh tersebut bebas dari sanksi pelanggaran. Mandor panen bertugas menegur langsung buruh yang melakukan tindakan tidak disiplin. Perusahaan tidak pernah melarang pemanen mengajak istri atau anaknya untuk membantu ketika panen, tetapi ketika terjadi kecelakaan kerja perusahaan tidak bertanggung jawab serta gaji yang diberikan sesuai dengan premi pemanen itu sendiri, sehingga mandor tidak punya wewenang untuk menegur. Pemanen di PT Harapan Sawit Lestari Cargill rata-rata istrinya juga bekerja baik sebagai perawatan atau pembrondol sawit sehingga jarang ditemukan istri yang membantu pemanen dalam bekerja, kecuali ketika diluar jam kerja. Mandor panen juga berhak memberikan kesempatan bagi buruh untuk menyampaikan pendapat yang baik dan ikut serta mengambil keputusan apabila terdapat masalah yang mendesak.

\section{KESIMPULAN}

Tingkat kedisiplinan buruh PT. Harapan Sawit Lestari Cargill Ketapang masuk dalam kategori baik. Variabel keadilan, balas jasa, ketegasan berpengaruh terhadap kedisiplin kerja pemanen kelapa sawit di PT. Harapan Sawit Lestari Cargill Ketapang.

\section{DAFTAR PUSTAKA}

Guo, T. (2019). Does the regional sense of social fairness really narrow the executive-employee pay gap? Modern Economy, 10(6), 1558-1580. https://doi.org/10.4236/me.2019.106103.

Handoko, T. H. (2003). Manajemen. 2nd ed. Yogyakarta: BPFE Yogyakarta.

Hasibuan. (2009). Manajemen Sumber Daya Manusia. Jakarta: Gunung Agung.

Meilani, N. (2020). Evaluasi sistem premi panen terhadap kinerja karyawan panen pada perkebunan kelapa sawit (Elaeis guineensis Jacq.) di PT. Sentosa Kalimantan Jaya. Jurnal Agriment, 5(02), 123-31. https://doi.org/10.51967/ jurnalagriment.v5i02.299.

Munajat. (2013). Pengaruh premi panen terhadap kinerja pemanen dan produksi tandan buah segar (TBS) kelapa sawit PT Minanga Ogan Kabupaten Ogan Komering Ulu. Journal of Chemical Information and Modeling, 53(9), 16891699.

Notoatmodjo, S. (2009). Pengembangan Sumber Daya Manusia. Jakarta: Rineka Cipta.

Prijodarminto, S. (2004). Disiplin Kiat Menuju Sukses. Jakarta: Pratnya Pramito.

Putra, S. P., Asmony, T., \& Nasir, M. (2016). Beberapa faktor yang memengaruhi disiplin kerja pegawai negeri sipil Puskesmas Se Kabupaten Dompu. Jurnal Pendidikan Mandala, 1(1), 297-306. http://dx.doi.org/10.36312/jupe.v1i1.141. 
Fatoni, C. A., Kurniati, D., Suharyani, A. : Disiplin Kerja Pemanen Kelapa Sawit ...

Samosir, R. \& Bahri, S. (2017). Perempuan pekerja kebun sawit di Desa Bukit Agung Kecamatan Kerinci Kanan Kabupaten Siak. JOM FISIP, 4(2), 1-9.

Setiawan, Y. (2011). Pengaruh ketegasan dan kepuasan kerja terhadap disiplin kerja karyawan [Thesis]. Unika Soegijapranata, Semarang.

Silaban, C. G, Suswatiningsih, T. E., \& Wirianata, H. (2016). Pengaruh tingkat pendidikan karyawan terhadap kinerja karyawan perkebunan kelapa sawit. Jurnal Agromast, 1(2), 1-23.

Sipriani, D., Priyono, B. S., \& Purwoko, A. (2017). Faktor-faktor yang memengaruhi produktivitas tenaga kerja pemanen sawit PT. Desaria Plantation Mining di Kecamatan Kinal Kabupaten Kaur. Bisnis Tani, 3 (2), 125-132. https://doi.org/10.35308/jbt.v3i2.365.

Suma'mur. (2009). Hiegiene Perusahaan Dan
Keselamatan Kerja. Jakarta: Sagung Seto.

Suryani, A. S. (2013). Pengaruh faktor kompensasi terhadap kepuasaan kerja dosen pada Akademi Keperawatan Rumah Sakit Marthe Indey Jayapura. Jurnal Uniya, 3(11), 1-23.

Sutrisna, E. \& Ulina, M. (2015). Pengaruh disiplin kerja terhadap produksi kerja karyawan PT. Perkebunan Nusantara V PKS Sei Sokan (Kasus karyawan bagian pengolahan). JOM FISIP, 2(1), 1-9.

Sutrisno, E. (2011). Manajemen Sumber Daya Manusia. Jakarta: Kencana Prenada Media Group.

Utari, K. (2015). Pengaruh kepemimpinan dan pengawasan melekat terhadap disiplin kerja pegawai di Dinas Pertambangan Dan Energi Kabupaten Kutai Timur." Pemerintahan Integratif, 3(1), 31-45. 